\title{
Tropomyosin Beta Chain
}

National Cancer Institute

\section{Source}

National Cancer Institute. Tropomyosin Beta Chain. NCI Thesaurus. Code C115003.

Tropomyosin beta chain (284 aa, $\sim 33 \mathrm{kDa}$ ) is encoded by the human TPM2 gene. This protein plays a role in muscle contraction. 